\title{
Metal-free graphene quantum dots photosensitizer coupled with nickel phosphide cocatalyst for enhanced photocatalytic hydrogen production in water under visible light
}

\author{
Liang Zhu, Qiudi Yue, Daochuan Jiang, Huanlin Chen, Rana Muhammad Irfan, Pingwu Du* \\ Hefei National Laboratory for Physical Sciences at the Microscale, iChEM (Collaborative Innovation Center of Chemistry for Energy Materials), CAS Key \\ Laboratory of Materials for Energy Conversion, Department of Materials Science and Engineering, University of Science and Technology of China, Hefei \\ 230026, Anhui, China
}

\section{A R T I C L E I N F O}

\section{Article history:}

Received 29 May 2018

Accepted 6 July 2018

Published 5 November 2018

\section{Keywords:}

Noble-metal-free

Photocatalysis

Hydrogen production

$\mathrm{OH}$-functionalized graphene quantum dotts

$\mathrm{Ni}_{2} \mathrm{P}$

\begin{abstract}
A B S T R A C T
Photocatalytic hydrogen $\left(\mathrm{H}_{2}\right)$ evolution is a promising approach for future sustainable energy utilization. However, it is still a great challenge to develop efficient and stable metal-free photocatalysts with broadband solar absorption in the visible region for $\mathrm{H}_{2}$ production. Metal-free graphene quantum dot (GQD) is an emerging candidate for this purpose because of its good water-solubility and tunable band gap. On the other hand, metal phosphides $\left(\mathrm{Ni}_{2} \mathrm{P}, \mathrm{Co}_{2} \mathrm{P}\right.$, etc) have been demonstrated as novel noble-metal-free cocatalysts for water splitting, which can efficiently separate electron-hole pairs and enhance the photocatalytic activities. Herein, we report for the first time on the use of OH-functionalized GQDs (OH-GQDs) photosensitizer coupled with $\mathrm{Ni}_{2} \mathrm{P}$ nanoparticles for photocatalytic $\mathrm{H}_{2}$ production with $\lambda>420 \mathrm{~nm}$ light. The $\mathrm{H}_{2}$ production rate is $\sim 94$ times higher than that of bare OH-GQDs, which is even comparable to that of OH-GQDs with $1.0 \mathrm{wt} \% \mathrm{Pt}$ cocatalyst. This enhancement is probably due to the semiconductor-cocatalyst interface interaction between $\mathrm{Ni}_{2} \mathrm{P}$ and OH-GQDs to facilitate efficient charge transfer process.
\end{abstract}

(C) 2018, Dalian Institute of Chemical Physics, Chinese Academy of Sciences. Published by Elsevier B.V. All rights reserved.

\section{Introduction}

The development of clean and renewable energy resources has been one of the hot subjects in recent decades due to the global energy crisis and environmental issues [1,2]. Semiconductor mediated photocatalysis to produce $\mathrm{H}_{2}$ is a promising method to solve this problem [3-6]. In the past decades, many efforts have been made to find suitable semiconductors for this purpose, such as $\mathrm{TiO}_{2}$ [7-9], CdS [10-14], TaON [15,16]. Recently, metal-free nanocarbon-based photocatalysts have attracted increasing interest due to their following advantages: low cost, environmental friendly, and good stability [17-21].
Among them, graphene quantum dots (GQDs) have been suggested as a promising alternative to the conventional semiconductor quantum dots because of their unique properties such as high water-solubility, low toxicity, excellent biocompatibility, and high photostability [22-24]. Moreover, the band gaps of GQDs can be flexibly tuned by controlling the particle size and ligand species [25,26].

So far, bare metal-free GQDs have not been explored as a good photocatalyst for $\mathrm{H}_{2}$ production under visible light, which is probably due to its short excitation lifetime, leading to fast electron-hole recombination, and thus poor photocatalytic efficiency $[27,28]$. The GQDs coupled with an efficient cocatalyst

\footnotetext{
* Corresponding author. Tel/Fax: +86-551-63606207; E-mail: dupingwu@ustc.edu.cn

This work was supported by the National Key Research and Development Program of China (2017YFA0402800), the National Natural Science Foundation of China (51772285, 21473170), and the Fundamental Research Funds for the Central Universities.

DOI: 10.1016/S1872-2067(18)63135-3 | http://www.sciencedirect.com/science/journal/18722067 | Chin. J. Catal., Vol. 39, No. 11, November 2018
} 
can probably solve this problem because of the existing fact of improved charge transfer from a semiconductor to a cocatalyst $[29,30]$. Traditionally, noble metals (such as $\mathrm{Pt}, \mathrm{Ru}$, and Pd) are regarded as the best cocatalysts for photocatalytic $\mathrm{H}_{2}$ evolution when integrated with a semiconductor [31,32]. However, their high costs make it less attractive for practical application. In our previous studies [33-36], we found that metal phosphides could serve as good cocatalysts to enhance photocatalytic $\mathrm{H}_{2}$ production. Among them, $\mathrm{Ni}_{2} \mathrm{P}$ nanoparticles (NPs) were proved to be the most promising candidate as cocatalyst considering its good electrical conductivity and simple synthesis process $[37,38]$.

Inspired by our previous studies, herein we report the use of water-soluble $\mathrm{OH}$-functionalized graphene quantum dots (OH-GQDs) as the photosensitizer coupled with noble-metal-free $\mathrm{Ni}_{2} \mathrm{P}$ NPs as the cocatalyst for visible-light driven $\mathrm{H}_{2}$ production. Under optimal conditions, the highest photocatalytic $\mathrm{H}_{2}$ evolution rate can reach $1567 \mu \mathrm{mol} \cdot \mathrm{h}^{-1} \cdot \mathrm{g}^{-1}$, which is $~ 94$ times higher than that of bare OH-GQDs, suggesting that metal-free photosensitizer OH-GQDs coupled with noble-metal-free $\mathrm{Ni}_{2} \mathrm{P}$ cocatalyst is efficient for photocatalytic $\mathrm{H}_{2}$ evolution.

\section{Experimental}

\subsection{Materials}

All chemicals, including Pyrene $\left(\mathrm{C}_{16} \mathrm{H}_{10}, 98.0 \%\right)$, Sodium hydroxide ( $\mathrm{NaOH}, 96.0 \%)$, nitric acid $\left(\mathrm{HNO}_{3}, 65 \sim 68 \%\right)$, ethylenediamine $\left(\mathrm{C}_{2} \mathrm{H}_{4}\left(\mathrm{NH}_{2}\right)_{2}, 99.0 \%\right)$, nickel nitrate hexahydrate $\left(\mathrm{Ni}\left(\mathrm{NO}_{3}\right)_{2} \cdot 6 \mathrm{H}_{2} \mathrm{O}, 98.0 \%\right)$, triethanolamine (TEOA, 99\%), ascorbic acid (VC, 99.7\%), methanol $\left(\mathrm{CH}_{3} \mathrm{OH}, 99.5 \%\right)$, sodium sulfide nonahydrate $\left(\mathrm{Na}_{2} \mathrm{~S} \cdot 9 \mathrm{H}_{2} \mathrm{O}, 99.0 \%\right)$, and anhydrous sodium sulfate $\left(\mathrm{Na}_{2} \mathrm{SO}_{3}, 97.0 \%\right)$, were commercially available (Aldrich and Innochem) and used without further purification.

\subsection{Preparation of $\mathrm{OH}-G Q D s$}

OH-GQDs were prepared according to a previous report with some modifications [39]. In a typical procedure, $2.0 \mathrm{~g}$ pyrene was nitrated into trinitropyrene in $160 \mathrm{~mL}$ hot $\mathrm{HNO}_{3}$ at 80 ${ }^{\circ} \mathrm{C}$ under refluxing and stirring for $12 \mathrm{~h}$. After cooling to room temperature, the trinitropyrene was collected by centrifugation. The resulting yellow precipitates were dispersed in $30 \mathrm{~mL}$ $\mathrm{NaOH}$ solution $(0.2 \mathrm{~mol} / \mathrm{L})$ by ultrasonication for $150 \mathrm{~min}$. The suspension was transferred to a Teflon-lined autoclave $(50 \mathrm{~mL})$ and heated for $10 \mathrm{~h}$ at $200{ }^{\circ} \mathrm{C}$. After cooling to room temperature, the product containing water-soluble OH-GQDs was filtered through a $0.22 \mathrm{~mm}$ microporous membrane and then dialysed in a dialysis bag for $48 \mathrm{~h}$. After that, the purified black $\mathrm{OH}-\mathrm{GQD}$ were dried at $80^{\circ} \mathrm{C}$ under vacuum.

\subsection{Preparation of $\mathrm{Ni}_{2} \mathrm{P} \mathrm{NPS}$}

$\mathrm{Ni}_{2} \mathrm{P}$ NPs were synthesized according to our previous study [35]. Typically, a certain amount of $\mathrm{Ni}\left(\mathrm{NO}_{3}\right)_{2} \cdot 6 \mathrm{H}_{2} \mathrm{O}$ and yellow phosphorus (1:5) were dissolved in ethylenediamine and stirred for $30 \mathrm{~min}$. Then, the mixed solution was transferred to a 50-mL Teflon-lined, stainless-steel autoclave and maintained at $140{ }^{\circ} \mathrm{C}$ for $12 \mathrm{~h}$. After cooling to room temperature, the product was collected and washed with benzene, ethanol, and distilled water three times each.

\subsection{Characterization}

The crystal structures of the OH-GQDs and $\mathrm{Ni}_{2} \mathrm{P}$ were characterized by powder X-ray diffraction (XRD, D/m/ax-TTR III) using graphite monochromatized $\mathrm{Cu} K_{\alpha}$ radiation of 0.154178 $\mathrm{nm}$, operating at $40 \mathrm{kV}$ and $200 \mathrm{~mA}$. The scanning range was from $10^{\circ}$ to $70^{\circ}(2 \theta)$ at the speed of $10^{\circ} \mathrm{min}^{-1}$. Scanning electron microscopy (SEM) was performed on JSM-6700F. Transmission electron microscopy (TEM) images was collected on a JEM-2010 electron microscope, operated at an acceleration voltage of $200 \mathrm{kV}$. The chemical composition was analyzed by X-ray photoelectron spectroscopy (XPS, ESCALAB 250 X-ray photoelectron spectrometer). Ultraviolet-visible (UV-vis) diffuse reflection spectra were investigated by using an UV-visible spectrophotometer (SOLID $3700 \mathrm{UV}$-vis spectrometer) over the range of 300 to $800 \mathrm{~nm}$. The photoluminescence (PL) spectra were recorded on a FluoroMax-4 spectrometer at ambient temperature. Fourier transformed-Infrared spectroscopy (FTIR) spectra of dried samples were studied on a Thermo Fisher Scientific instrument (Nicolet iS10).

\subsection{Photocatalytic hydrogen production}

Photocatalytic $\mathrm{H}_{2}$ evolution experiments were carried out in a $50 \mathrm{~mL}$ round-bottom flask at room temperature. A $300 \mathrm{~W}$ Xe-lamp equipped with a $420 \mathrm{~nm}$ cut-off filter was used to provide the visible light irradiation. In a typical run, $6 \mathrm{mg}$ of the photocatalyst and $1.2 \mathrm{mg}$ of the cocatalyst were dispersed in a mixed solution containing $18 \mathrm{~mL}$ water and $2 \mathrm{~mL}$ TEOA. Prior to irradiation, the solution was bubbled with high purity nitrogen for $15 \mathrm{~min}$ to remove the air inside. After that, $5 \mathrm{~mL}$ of methane was injected into the flask as the internal standard. The amount of produced $\mathrm{H}_{2}$ was calculated by a gas chromatograph (GC) equipped with a thermal conductivity detector (TCD) detector. For long-term irradiation, $20 \mathrm{mg}$ of the photocatalyst and $4 \mathrm{mg}$ of the cocatalyst were dispersed in a mixed solution containing $45 \mathrm{~mL}$ water and $5 \mathrm{~mL}$ TEOA and a $250 \mathrm{~mL}$ flask were used.

The apparent quantum yield (AQY) was measured using a $300 \mathrm{~W}$ Xe-lamp equipped with a $420 \mathrm{~nm}( \pm 5 \mathrm{~nm})$ band-pass cut filter. The light intensity was approximately $6.8 \mathrm{~mW} \mathrm{~cm}^{-2}$ and the illuminated area for the reactor was approximately $27 \mathrm{~cm}^{2}$. The AQY was calculated based on the following equation (1):

$$
\begin{aligned}
& \text { AQY }=\frac{\text { number of reacted electrons }}{\text { number of incident photons }} \times 100 \% \\
= & \frac{\text { number of evolved } \mathrm{H}_{2} \text { molecules } \times 2}{\text { number of incident photons }} \times 100 \%
\end{aligned}
$$

\section{Results and discussion}




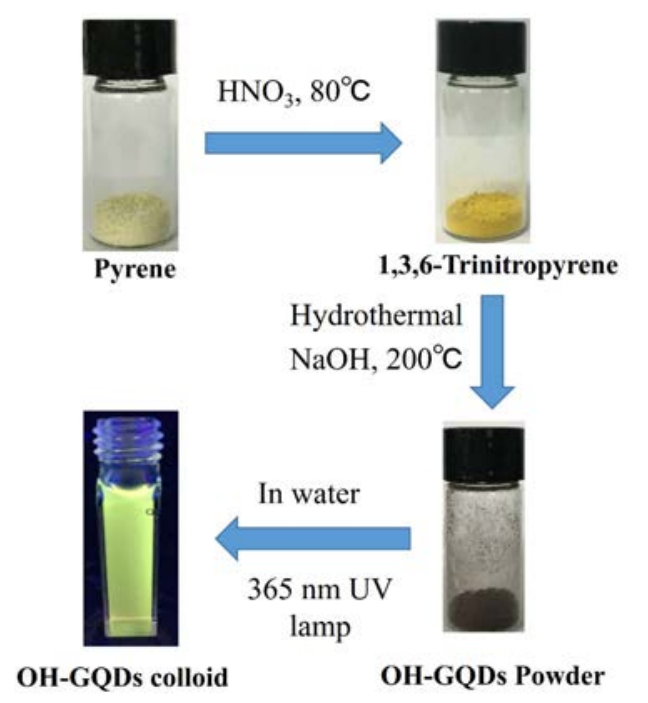

Fig. 1. Synthetic procedure of $\mathrm{OH}$-functionalized GQDs.

The synthesis process of the OH-GQDs is shown in the Fig. 1 [39]. Typically, pyrene was nitrated in hot $\mathrm{HNO}_{3}$ solution, followed by hydrothermal treatment in $\mathrm{NaOH}$ aqueous solution, and the as-prepared solution containing OH-GQDs was filtered. The filtrate was then dialysed in a dialysis bag for $48 \mathrm{~h}$ and dried at $80{ }^{\circ} \mathrm{C}$ under vacuum. The OH-GQDs solution emits strong green fluorescence when irradiated under $365 \mathrm{~nm}$ UV light.
The structure of the OH-GQDs was characterized by XRD. The characteristic feature of graphite with a (002) layer spacing is clearly observed (Fig. 2(a)), which is consistent with that of bulk graphite $(0.33 \mathrm{~nm})$ [40]. Moreover, Fig. 2(b) shows the FTIR spectra of bare OH-GQDs. The peak at $1618 \mathrm{~cm}^{-1}$ can be assigned to the $\mathrm{C}=\mathrm{C}$ bond stretch, and a strong, rather broad vibration at $3448 \mathrm{~cm}^{-1}$ is attributed to the $\mathrm{O}-\mathrm{H}$ bonds [41]. Noticeably, a peak at $1271 \mathrm{~cm}^{-1}$ is also observed, corresponding to the vibration of $\mathrm{C}-\mathrm{OH}[42,43]$. All these results confirmed that the OH-GQDs were successfully synthesized. Furthermore, the surface chemical composition of the OH-GQDs was also studied by the EDX spectra. Fig. 2(c) shows the existence of $\mathrm{C}, \mathrm{O}$, and $\mathrm{Cu}$ elements. It should be noted that $\mathrm{Cu}$ element should be from the $\mathrm{Cu}$ grid substrate. In addition, the morphology and the particle size of the OH-GQDs were investigated by TEM. As shown in Fig. 2(d), the OH-GQDs particles are well dispersed with uniform lateral sizes at $3.6 \pm 0.5 \mathrm{~nm}$. In addition, the XRD pattern of the as-prepared $\mathrm{Ni}_{2} \mathrm{P}$ cocatalyst shows good crystallinity (Fig. S1(a)). Fig. S1(b) is the SEM image of pure $\mathrm{Ni}_{2} \mathrm{P}$, in which small nanoparticles aggregated together with an average size of $\sim 300 \mathrm{~nm}$ were observed. The TEM image of $\mathrm{Ni}_{2} \mathrm{P} / \mathrm{OH}-\mathrm{GQDs}$ reveals that $\mathrm{OH}-\mathrm{GQD}$ are distributed randomly on $\mathrm{Ni}_{2} \mathrm{P}$ (Fig. 3).

The light absorption of the OH-GQDs covers almost the entire visible light region, which make it very interesting for photocatalysis. The UV-vis absorption spectrum of the OH-GQDs sample is shown in Fig. 4(a). As can be seen, the absorption spectrum of the OH-GQDs have two pronounced peaks, max-
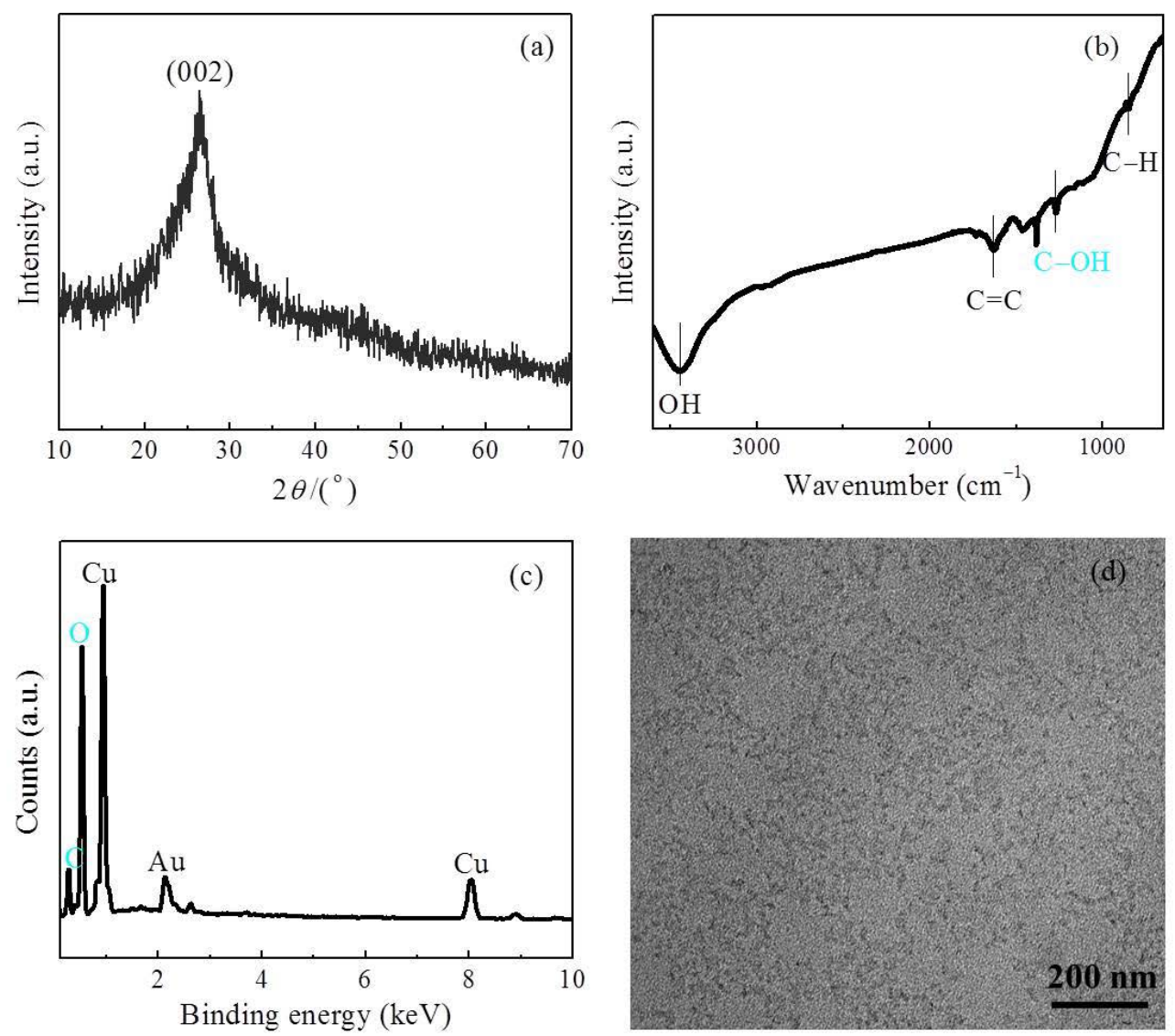

Fig. 2. Powder XRD pattern (a), FITR spectrum (b), EDX (c), and TEM image (d) of OH-GQDs. 


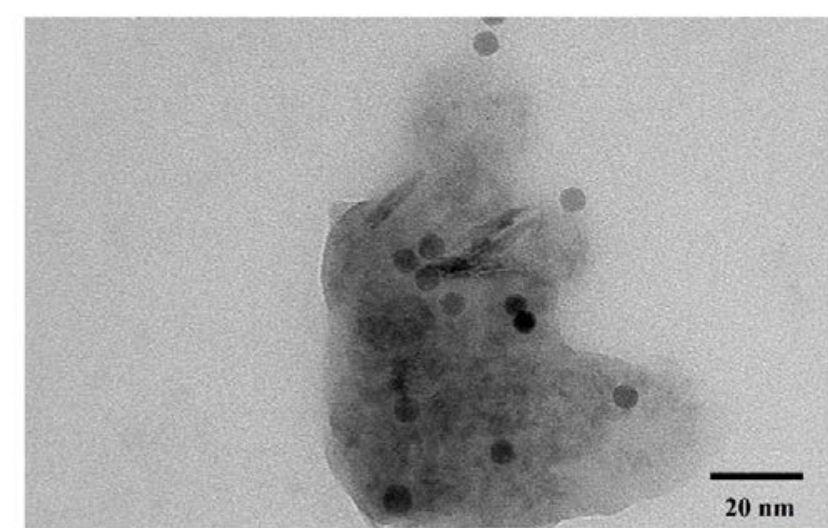

Fig. 3. TEM image of composite sample.

imized at about 350 and $490 \mathrm{~nm}$, with an optical absorption edge extended to $\sim 750 \mathrm{~nm}$ [44]. Its excellent absorbance in the visible region demonstrates great potential to generate $\mathrm{H}_{2}$ under visible light [45]. Moreover, PL spectra of the OH-GQDs were measured under different excitation wavelengths. As shown in Fig. 4(b), when the excitation wavelength changes from 315 to $390 \mathrm{~nm}$, the PL spectra have nearly the same features and show a strong emission peak at $\sim 540 \mathrm{~nm}$, suggesting a band gap of about $2.3 \mathrm{eV}$ [46].

To identify the surface chemical compositions and valence states of the photocatalyst and cocatalyst, XPS was used to measure the $\mathrm{OH}-\mathrm{GQD}$ and $\mathrm{Ni}_{2} \mathrm{P}$ samples. The high resolution $\mathrm{C}$ $1 s$ XPS spectrum shows four peaks at the binding energy (BE) of 284.8, 285.7, 288.4, and $289.8 \mathrm{eV}$ (Fig. 5(a)), which are ascribed to the strong signals of $\mathrm{C}=\mathrm{C}, \mathrm{C}-\mathrm{O}, \mathrm{C}-\mathrm{OH}$ and $\mathrm{C}=\mathrm{O}$, respectively $[39,47,48]$. Meanwhile, the high-resolution 0 1s XPS spectrum reveals the presence of $\mathrm{O}-\mathrm{H}$ at 531.6 and $533.1 \mathrm{eV}$ (Fig. 5(b)). The peak at $531.6 \mathrm{eV}$ belongs to OH-GQDs [39] and the signal at $533.1 \mathrm{eV}$ is assigned to the absorbed water $[49,50]$. The XPS results further confirmed the successful synthesis of $\mathrm{OH}$-functionalized GQDs. Moreover, the XPS spectrum of Ni $2 p$ (Fig. 5(c)) shows two main typical peaks (857.1 and $874.8 \mathrm{eV}$ ) with satellite peaks (marked as "Sat.") and a very weak peak at $853.3 \mathrm{eV}$ is attributed to $\mathrm{Ni}^{\delta+}$ of $\mathrm{Ni}_{2} \mathrm{P}$ [51]. The peaks at the BE of 857.1 and $874.8 \mathrm{eV}$, along with their satellite peaks, corre-

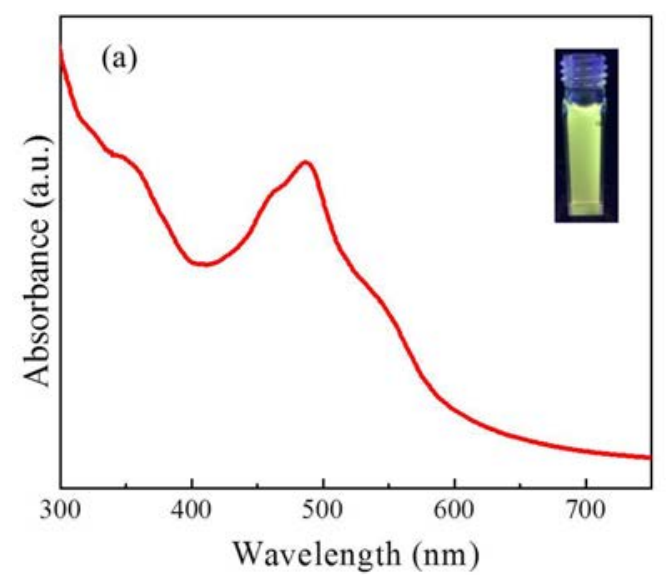

spond to the $\mathrm{Ni}^{2+}$ originating from surface oxidation state. Fig. 5 (d) gives the high resolution P $2 p$ XPS spectrum. The peaks at the $\mathrm{BE}$ of 129.3 and $130.2 \mathrm{eV}$ can be ascribed to the reduced phosphorus in the form of metal phosphides, while the peak at $134.1 \mathrm{eV}$ can be assigned to oxidized P species due to air exposure [52]. The XPS results further proved the formation of $\mathrm{Ni}_{2} \mathrm{P}$ with surface partially oxidized to phosphate.

Based on the above characterizations and analysis, the photocatalytic $\mathrm{H}_{2}$ production experiments of the present $\mathrm{OH}-\mathrm{GQDs}$ coupled with $\mathrm{Ni}_{2} \mathrm{P}$ cocatalyst $\left(\mathrm{Ni}_{2} \mathrm{P} / \mathrm{OH}-\mathrm{GQDs}\right)$ were further evaluated in aqueous solution under visible light $(\lambda>420 \mathrm{~nm})$ [53]. Firstly, the effect of different sacrificial agents was investigated $(0.75 \mathrm{~mol} / \mathrm{L}$ ascorbic acid, $\mathrm{pH}=4.2 ; 0.75 \mathrm{~mol} / \mathrm{L}$ methanol; $0.75 \mathrm{~mol} / \mathrm{L} \mathrm{TEOA;} 0.31 \mathrm{~mol} / \mathrm{L} \mathrm{Na} 2 \mathrm{~S} / 0.44 \mathrm{~mol} / \mathrm{L} \mathrm{Na}_{2} \mathrm{SO}_{3}$ ). The results show that only the TEOA solution can produce apparent $\mathrm{H}_{2}$, indicating that the weak alkaline condition might be favorable for photocatalytic $\mathrm{H}_{2}$ production using $\mathrm{Ni}_{2} \mathrm{P} / \mathrm{OH}-\mathrm{GQDs}$ (Fig. 6(a)). In order to explore the reason why only the TEOA solution can produce apparent $\mathrm{H}_{2}$, the PL spectra were measured. The concentrations of OH-GQDs for four different sacrificial agents are the same. As shown in Fig. S2(a), the emission intensity of $\mathrm{Ni}_{2} \mathrm{P} / \mathrm{OH}-\mathrm{GQDs}$ (black line) was significantly quenched when TEOA was added (red line), indicating that the electron-hole recombination can be efficiently suppressed in the presence of TEOA. However, for methanol and $\mathrm{Na}_{2} \mathrm{~S} / \mathrm{Na}_{2} \mathrm{SO}_{3}$, the PL intensities only slightly decreased (Fig. S2(b) and (c)). Interestingly, in the presence of VC (Figure S2d), the PL spectrum has been interrupted and damaged, which is probably caused by the VC solution. Based on the PL results, we can conclude that TEOA is the most efficient electron donor, which can quickly capture photo-generated holes and thus promoting the $\mathrm{H}_{2}$ evolution reaction.

Fig. 6(b) displays the rate of $\mathrm{H}_{2}$ production using bare OH-GQDs, bare $\mathrm{Ni}_{2} \mathrm{P}, \mathrm{Ni}_{2} \mathrm{P} / \mathrm{OH}-\mathrm{GQDs}$, and 1 wt\% Pt/OH-GQDs samples in $0.75 \mathrm{~mol} / \mathrm{L}$ TEOA solution [54]. As can be seen, $\mathrm{Ni}_{2} \mathrm{P}$ itself is not active for $\mathrm{H}_{2}$ evolution under visible light. Moreover, as for bare $\mathrm{OH}-\mathrm{GQDs}$, trace $\mathrm{H}_{2}$ production was detected, although it has a strong absorption band in visible region. The poor activity of pure OH-GQDs could be ascribed to the fast recombination of photo-generated electron-hole pairs [55]. Interestingly, it was found that an appropriate amount of $\mathrm{Ni}_{2} \mathrm{P}$

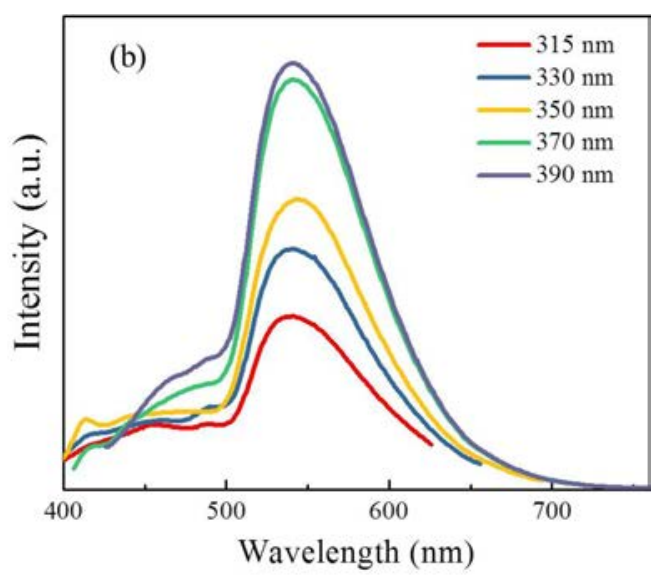

Fig. 4. (a) UV-Vis absorption spectrum of OH-GQDs dispersed in $3 \mathrm{~mL}$ water, the inset picture is the photograph of aqueous colloids of OH-GQDs under 365 nm light. (b) Photoluminescence spectra of OH-GQDs at different excitation wavelengths. 

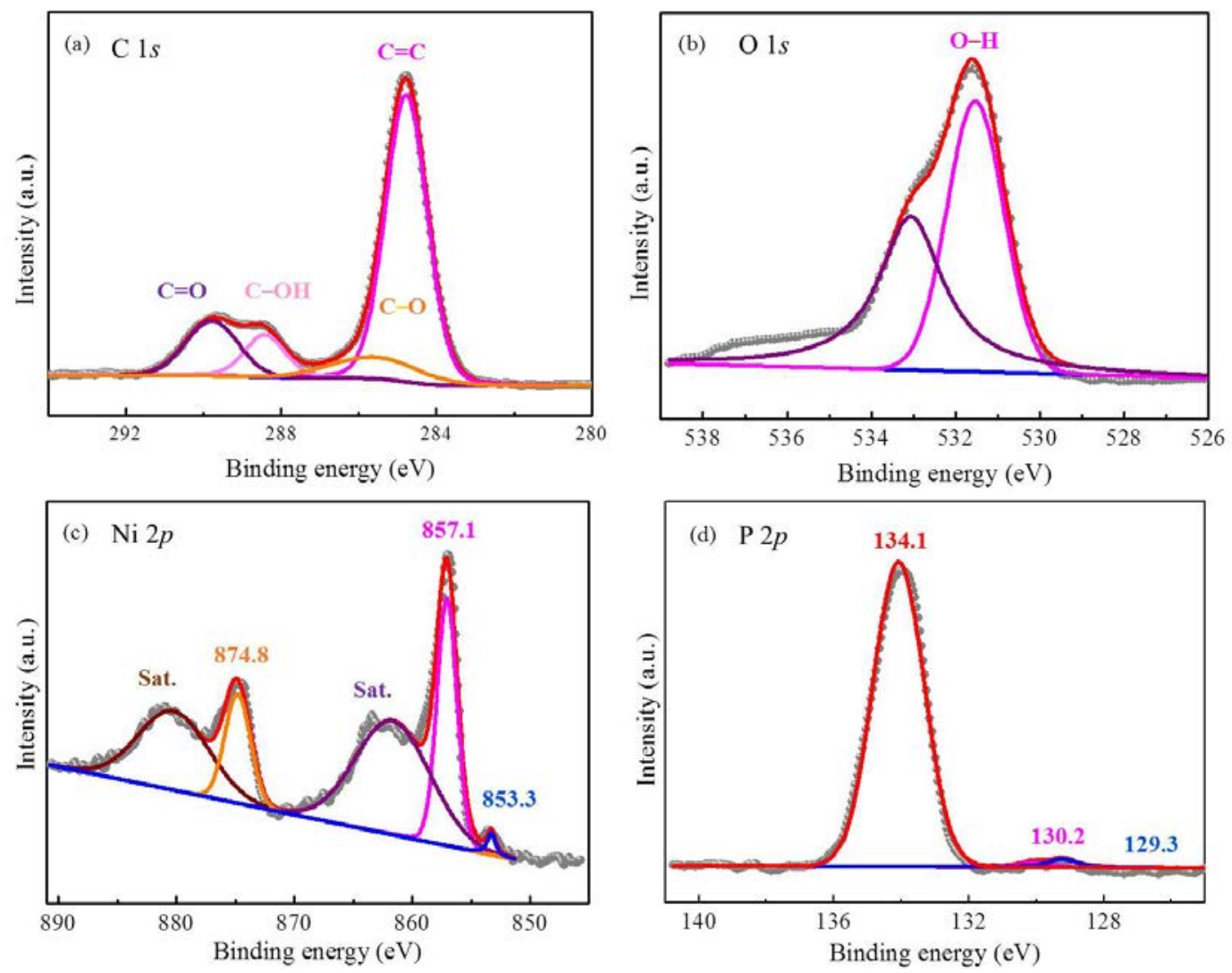

Fig. 5. High-resolution XPS spectra of C $1 s$ (a), $01 s$ (b), Ni $2 p$ (c), and P $2 p$ (d).

can significantly enhance the photocatalytic activity for $\mathrm{H}_{2}$ production using $\mathrm{Ni}_{2} \mathrm{P} / \mathrm{OH}-\mathrm{GQDs}$ sample. Noticeably, the rate of $\mathrm{H}_{2}$ evolution initially increased with the increasing amounts of $\mathrm{Ni}_{2} \mathrm{P}$ and then decreased with more amount of $\mathrm{Ni}_{2} \mathrm{P}$. The highest photocatalytic $\mathrm{H}_{2}$ evolution rate of $\sim 1567 \mu \mathrm{mol} \cdot \mathrm{h}^{-1} \cdot \mathrm{g}^{-1}$ was obtained when $20 \mathrm{wt} \% \mathrm{Ni}_{2} \mathrm{P}$ was used, which is comparable to the activity of $1 \mathrm{wt} \% \mathrm{Pt} / \mathrm{OH}-\mathrm{GQDs}\left(\sim 1683 \mu \mathrm{mol} \cdot \mathrm{h}^{-1} \cdot \mathrm{g}^{-1}\right)$. When the weight ratio of $\mathrm{Ni}_{2} \mathrm{P}$ reached more than $20 \mathrm{wt} \%$, the $\mathrm{H}_{2}$ evolution rate decreased $\left(\sim 1000 \mu \mathrm{mol} \cdot \mathrm{h}^{-1} \cdot \mathrm{g}^{-1}\right.$ for $\left.30 \mathrm{wt} \%\right)$, probably resulting from the fact that more $\mathrm{Ni}_{2} \mathrm{P}$ per unit area can shied the visible light absorption of OH-GQDs, leading to the decrease of photons absorbed. Interestingly, the present photocatalytic reaction system also showed good photocatalytic activity when the reaction solution was exposed to air (Fig. $6(\mathrm{c})$ ). All the above results suggest the importance of noble-metal-free $\mathrm{Ni}_{2} \mathrm{P}$ cocatalyst for the improvement of $\mathrm{H}_{2}$ evolution over OH-GQDs. To the best of our knowledge, this is the first time to explore the photocatalytic activity of OH-GQDs for $\mathrm{H}_{2}$ production coupled with a noble-metal-free cocatalyst.

The apparent quantum yield (AQY) for $\mathrm{H}_{2}$ evolution over the $20 \mathrm{wt} \% \mathrm{Ni}_{2} \mathrm{P} / \mathrm{OH}-\mathrm{GQDs}$ photocatalyst was performed in a system containing $0.75 \mathrm{~mol} / \mathrm{L}$ TEOA under a monochromatic light at $420 \mathrm{~nm}( \pm 5 \mathrm{~nm})$. As shown in Fig. 6(d), the AQY increases with the irradiation time, especially in the initial stage, which may be due to an induction period and the dissolved $\mathrm{H}_{2}$ in the solution [35]. $\mathrm{H}_{2}$ was not detected until the sample was irradiated for $2 \mathrm{~h}$. The AQY is only $0.2 \%$ for the second hour and then reaches to $0.64 \%$ with a $\mathrm{H}_{2}$ evolution rate up to $\sim 428.5$ $\mu \mathrm{mol} \cdot \mathrm{h}^{-1} \cdot \mathrm{g}^{-1}$ after $8 \mathrm{~h}$ of irradiation. The average AQY is $0.46 \%$ in the evaluated time. Meanwhile, the stability of the $\mathrm{Ni}_{2} \mathrm{P} / \mathrm{OH}-\mathrm{GQDs}$ under a $300 \mathrm{~W}$ Xe lamp with a $420 \mathrm{~nm}( \pm 5 \mathrm{~nm})$ band-pass filter was also studied (Fig. 7(a)). No significant decrease for photocatalytic $\mathrm{H}_{2}$ production was observed. After 28 $\mathrm{h}$ of irradiation, a total amount of $\sim 199.8 \mu \mathrm{mol} \mathrm{H} 2$ was produced at a constant rate of $\sim 440 \mu \mathrm{mol} \cdot \mathrm{h}^{-1} \cdot \mathrm{g}^{-1}$, suggesting excellent durability of the $\mathrm{Ni}_{2} \mathrm{P} / \mathrm{OH}-\mathrm{GQD}$ for photocatalytic $\mathrm{H}_{2}$ production under visible light.

In order to explore the reaction mechanism for photocatalytic $\mathrm{H}_{2}$ production over $\mathrm{Ni}_{2} \mathrm{P} / \mathrm{OH}-\mathrm{GQDs}$, the Mott-Schottky plot and PL measurements were examined to study the photoinduced electron transfer behavior. Fig. 7(b) shows the Mott-Schottky plot of OH-GQDs in a $\mathrm{H}_{2} \mathrm{SO}_{4}$ solution (1.0 mol/L) and the positive slope indicates n-type conductivity [56]. Moreover, the Fermi levels $\left(E_{\mathrm{Fn}}\right)$ of the OH-GQDs could be gained from the $\mathrm{X}$-intercept by extrapolating the $\mathrm{M}-\mathrm{S}$ plot to $1 / C^{2}=0$, and the values for the sample is about $-0.52 \mathrm{~V}$ vs. NHE, which is consistent with previous reports $[27,28]$. Therefore, the conduction band of the OH-GQDs is more negative than $-0.52 \mathrm{~V}$ vs. NHE $\left(E_{\mathrm{Fn}}\right)$. In the previous studies, the photo-excited carriers can be swiftly transferred from the CB of CdS $(-0.5 \mathrm{~V}$ vs. the NHE) to $\mathrm{Ni}_{2} \mathrm{P}$, which acts as an excellent cocatalyst $[57,58]$. Since the CB edge of OH-GQDs is more negative than that of CdS, the photo-excited electrons on OH-GQDs could be transferred to $\mathrm{Ni}_{2} \mathrm{P}$ through the $\mathrm{Ni}_{2} \mathrm{P} / \mathrm{OH}-\mathrm{GQD}$ interface. The emission intensity was obviously quenched upon adding $\mathrm{Ni}_{2} \mathrm{P}$ to the OH-GQDs solution (Fig. 7(c)), indicating $\mathrm{Ni}_{2} \mathrm{P}$ can suppress the electron-hole recombination $[59,60]$. According to the aforementioned results, a probable reaction mechanism for the 

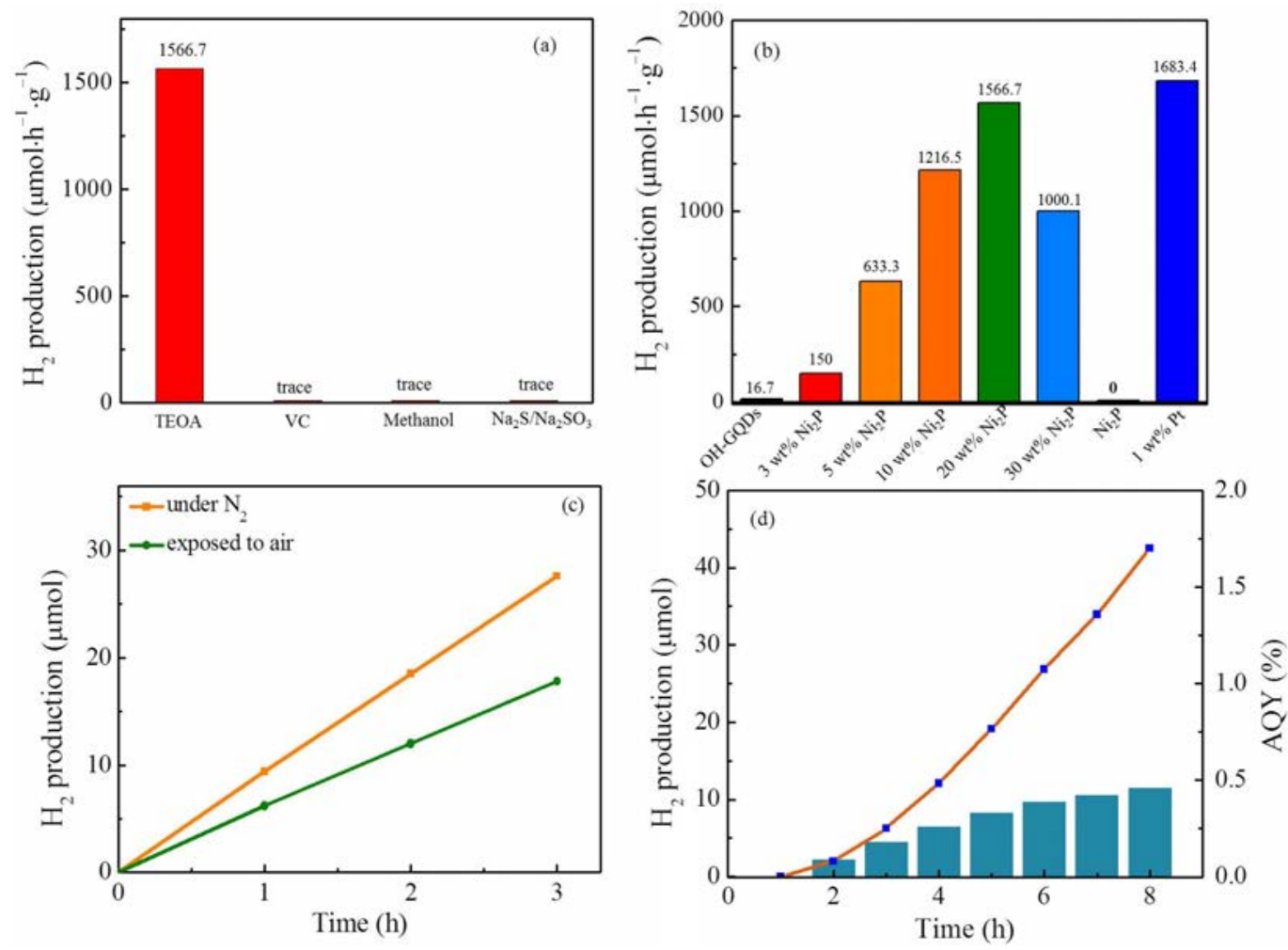

Fig. 6. (a) Hydrogen production rate on $20 \mathrm{wt} \% \mathrm{Ni}_{2} \mathrm{P} / \mathrm{OH}-\mathrm{GQD}$ photocatalyst with different types of the hole scavenger (TEOA, VC, methanol, and $\mathrm{Na}_{2} \mathrm{~S} / \mathrm{Na}_{2} \mathrm{SO}_{3}$ ) at room temperature under visible light $\left(\lambda>420 \mathrm{~nm}\right.$ ). (b) The rate of $\mathrm{H}_{2}$ evolution over $\mathrm{Ni}_{2} \mathrm{P} / \mathrm{OH}-\mathrm{GQDs}$ photocatalyst hybrid with different amounts of $\mathrm{Ni}_{2} \mathrm{P}$ at room temperature under visible light $(\lambda>420 \mathrm{~nm})$, and comparison of photocatalytic $\mathrm{H}_{2}$ evolution with 1 wt\% Pt. The system contains $6 \mathrm{mg}$ photocatalyst, $1.2 \mathrm{mg}$ cocatalyst and $2 \mathrm{~mL}$ TEOA in $18 \mathrm{~mL}$ deionized water. (c) Comparison of photocatalytic $\mathrm{H}_{2}$ evolution under $\mathrm{N}_{2}$ and in air. Both systems contain the same components: $18 \mathrm{~mL} \mathrm{H}_{2} \mathrm{O}$ and $2 \mathrm{~mL}$ TEOA in the presence of 6 mg photocatalyst and $1.2 \mathrm{mg}$ cocatalyst. (d) The time courses of $\mathrm{H}_{2}$ evolution and the average apparent quantum yield (AQY) over the $20 \mathrm{wt} \% \mathrm{Ni} 2 \mathrm{P} / \mathrm{OH}$-GQDs photocatalyst under monochromatic $420 \mathrm{~nm}$ light irradiation. The bars denote the apparent quantum yield.
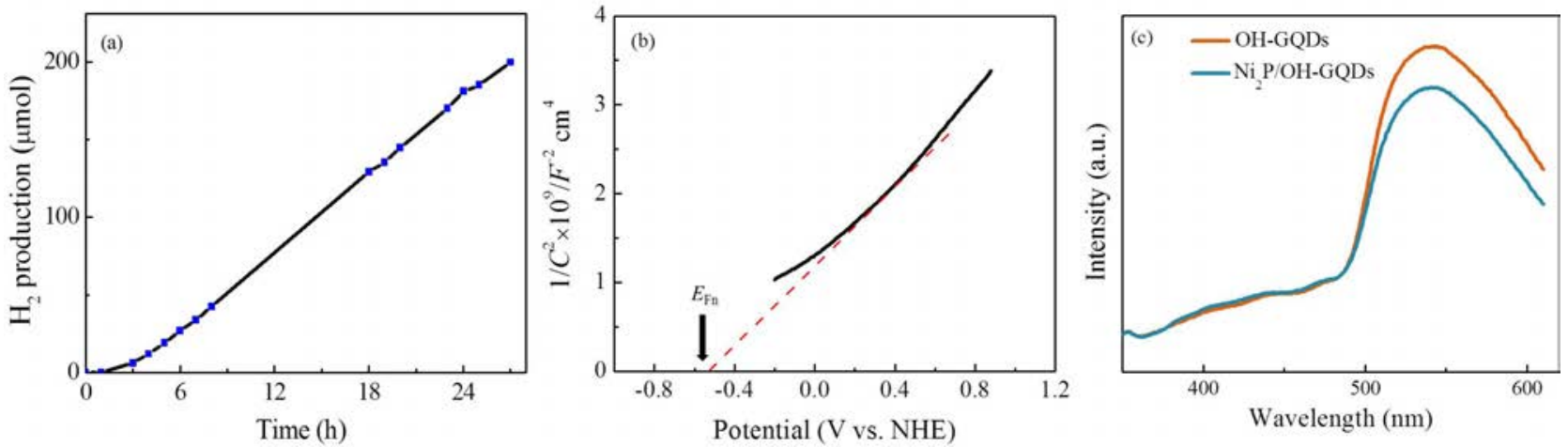

Fig. 7. (a) Long-term production of $\mathrm{H}_{2}$ for $28 \mathrm{~h}$ under monochromatic $420 \mathrm{~nm}$ light irradiation using $20 \mathrm{wt} \% \mathrm{Ni}_{2} \mathrm{P} / \mathrm{OH}$-GQDs photocatalyst at room temperature. (b) Mott-Schottky curve of OH-GQDs in $1.0 \mathrm{~mol} / \mathrm{L} \mathrm{H}_{2} \mathrm{SO}_{4}$. (c) Spectra performance of the pure OH-GQDs and $20 \mathrm{wt} \% \mathrm{Ni} 2 \mathrm{P} / \mathrm{OH}-\mathrm{GQDs}$ photocatalyst at an excitation wavelength of $315 \mathrm{~nm}$ at room temperature.

enhanced photocatalytic activity of the $\mathrm{Ni}_{2} \mathrm{P} / \mathrm{OH}-\mathrm{GQDs}$ is proposed. As shown in Scheme 1, OH-GQDs $\left(E_{\mathrm{g}}=2.3 \mathrm{eV}\right)$ can effectively absorb visible light to excite electrons located at the valence band (VB) to the conduction band (CB), accompanied by the creation of photogenerated electron-hole pairs [61]. In addition, $\mathrm{Ni}_{2} \mathrm{P}$ shows metallic character and can not absorb visible light to produce electron-hole pairs [62]. Due to the introduction of $\mathrm{Ni}_{2} \mathrm{P}$ on $\mathrm{OH}-\mathrm{GQDs}$, a typical metal-semiconductor interface was formed. Then, the photo-generated electrons in the $\mathrm{CB}$ of OH-GQDs rapidly moved to the surface of the $\mathrm{Ni}_{2} \mathrm{P}$ NPs and the holes could be consumed by TEOA, and thus promoting separation of the electron-hole pairs and suppressing their recombination. Finally, the electrons on the surface of $\mathrm{Ni}_{2} \mathrm{P}$ will catalyze the reduction of protons to produce $\mathrm{H}_{2}$, resulting in the improved photocatalytic $\mathrm{H}_{2}$ production activity.

\section{Conclusions}

In summary, we studied the use of OH-GQDs as a metal-free photosensitizer for photocatalytic $\mathrm{H}_{2}$ evolution under visible 


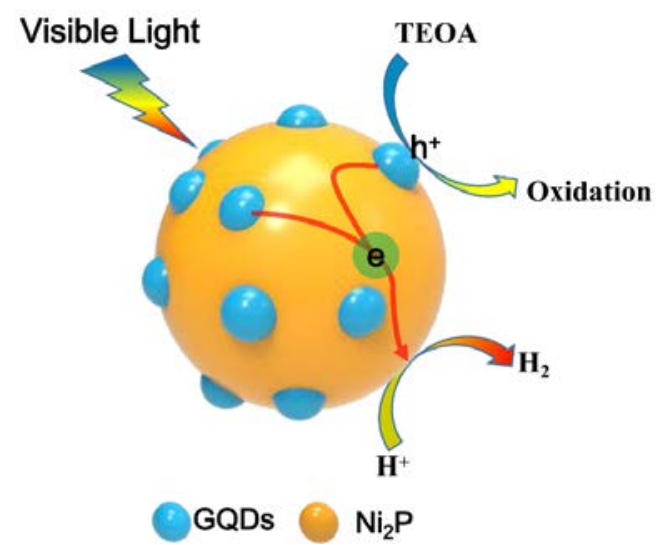

Scheme 1. Schematic illustration of the mechanisms for the photocatalytic $\mathrm{H}_{2}$ evolution over $\mathrm{Ni}_{2} \mathrm{P} / \mathrm{OH}-\mathrm{GQDs}$ under visible light irradiation.

light. The photocatalytic activity can be significantly enhanced by the addition of noble-metal-free $\mathrm{Ni}_{2} \mathrm{P}$ cocatalyst. Under optimal conditions, the photocatalyst sample exhibited a maximum $\mathrm{H}_{2}$ evolution rate of $1567 \mu \mathrm{mol} \cdot \mathrm{h}^{-1} \cdot \mathrm{g}^{-1}$, which is $\sim 94$ times higher than that of bare OH-GQDs and comparable to the catalytic activity of $1 \mathrm{wt} \% \mathrm{Pt} / \mathrm{OH}-\mathrm{GQDs}$ sample $\left(1683 \mu \mathrm{mol} \cdot \mathrm{h}^{-1} \cdot \mathrm{g}^{-1}\right)$. All the results indicate that $\mathrm{Ni}_{2} \mathrm{P}$ can efficiently promote the separation of photo-generated charge carriers and highly enhance photocatalytic $\mathrm{H}_{2}$ evolution of OH-GQDs. This present study demonstrates that the OH-GQDs is an efficient metal-free catalyst for photocatalytic $\mathrm{H}_{2}$ evolution coupled with a suitable cocatalyst.

\section{References}

[1] A. J. Esswein, D. G. Nocera, Chem. Rev., 2007, 107, 4022-4047.

[2] X. Zou, Y. Zhang, Chem. Soc. Rev., 2015, 44, 5148-5180.

[3] D. Chu, K. Li, A. Liu, J. Huang, C. Zhang, P. Yang, Y. Du, C. Lu, Int. J. Hydrogen Energy, 2018, 43, 7307-7316.

[4] P. Du, R. Eisenberg, Energy Environ. Sci., 2012, 5, 6012-6021.

[5] A. Kudo, Y. Miseki, Chem. Soc. Rev., 2009, 38, 253-278.

[6] Z. Zou, J. Ye, K. Sayama, H. Arakawa, Nature, 2001, 414, 625-627.

[7] X. Liu, Z. Xing, Y. Zhang, Z. Li, X. Wu, S. Tan, X. Yu, Q. Zhu, W. Zhou, Appl. Catal. B, 2017, 201, 119-127.

[8] O. Elbanna, S. Kim, M. Fujitsuka, T. Majima, Nano Energy, 2017, 35, 1-8.

[9] J. Wen, X. Li, W. Liu, Y. Fang, J. Xie, Y. Xu, Chin. J. Catal., 2015, 36, 2049-2070.

[10] Z. Yue, A. Liu, C. Zhang, J. Huang, M. Zhu, Y. Du, P. Yang, Appl. Catal. $B, 2017,201,202-210$.

[11] S. Ma, X. Xu, J. Xie, X. Li, Chin. J. Catal, 2017, 38, 1970-1980.

[12] D. Jiang, L. Zhu, R. M. Irfan, L. Zhang, P. Du, Chin. J. Catal., 2017, 38, 2102-2109.

[13] Y. Cui, Chin. J. Catal., 2015, 36, 372-379.

[14] L. J. Zhang, R. Zheng, S. Li, B. K. Liu, D. J. Wang, L. L. Wang, T. F. Xie, ACS Appl. Mater. Interfaces, 2014, 6, 13406-13412.

[15] W. Chen, M. Chu, L. Gao, L. Mao, J. Yuan, W. Shangguan, Appl. Surf. Sci., 2015, 324, 432-437.

[16] Z. Wang, J. Hou, C. Yang, S. Jiao, H. Zhu, Chem. Commun., 2014, 50, 1731-1734.

[17] X. Miao, D. Qu, D. Yang, B. Nie, Y. Zhao, H. Fan, Z. Sun, Adv. Mater, 2018, 30, 201870002.

[18] Z. Chen, C. Feng, W. Li, Z. Sun, J. Hou, X. Li, L. Xu, M. Sun, Y. Bu, Chin.
J. Catal., 2018, 39, 841-848.

[19] M. Zhu, C. Zhai, M. Sun, Y. Hu, B. Yan, Y. Du, Appl. Catal. B, 2017, 203, 108-115.

[20] B. Yuan, J. Wei, T. Hu, H. Yao, Z. Jiang, Z. Fang, Z. Chu, Chin. J. Catal., 2015, 36, 1009-1016.

[21] S. Y. Lim, W. Shen, Z. Gao, Chem. Soc. Rev., 2015, 44, 362-381.

[22] J. Qian, C. Shen, J. Yan, F. Xi, X. Dong, J. Liu, J. Phys. Chem. C, 2018, 122, 349-358.

[23] M. Ebrahimi, M. Samadi, S. Yousefzadeh, M. Soltani, A. Rahimi, T. C. Chou, L. C. Chen, K. H. Chen, A. Z. Moshfegh, ACS Sustainable Chem. Eng., 2016, 5, 367-375.

[24] H. Xu, S. Zhou, L. Xiao, H. Wang, S. Li, Q. Yuan, J. Mater. Chem. C, 2015, 3, 291-297.

[25] Y. Li, Y. Zhao, H. Cheng, Y. Hu, G. Shi, L. Dai, L. Qu, J. Am. Chem. Soc., 2011, 134, 15-18.

[26] D. Pan, J. Zhang, Z. Li, M. Wu, Adv. Mater., 2010, 22, 734-738.

[27] T. F. Yeh, S. J. Chen, H. Teng, Nano Energy, 2015, 12, 476-485.

[28] T. F. Yeh, C. Y. Teng, S. J. Chen, H. Teng, Adv. Mater., 2014, 26, 3297-3303.

[29] K. He, J. Xie, M. Li, X. Li, Appl. Surf. Sci., 2018, 430, 208-217.

[30] D. Lang, T. Shen, Q. Xiang, ChemCatChem, 2015, 7, 943-951.

[31] Q. Xu, B. Cheng, J. Yu, G. Liu, Carbon, 2017, 118, 241-249.

[32] W. Che, W. Cheng, T. Yao, F. Tang, W. Liu, H. Su, Y. Huang, Q. Liu, J. Liu, F. Hu, Z. Pan, Z. Sun, S. Wei, J. Am. Chem. Soc., 2017, 139, 3021-3026.

[33] Z. Sun, H. Chen, Q. Huang, P. Du, Catal. Sci. Technol., 2015, 5, 4964-4967.

[34] Z. Sun, Q. Yue, J. Li, J. Xu, H. Zheng, P. Du, J. Mater. Chem. A, 2015, 3, 10243-10247.

[35] Z. Sun, H. Zheng, J. Li, P. Du, Energy Environ. Sci, 2015, 8, 2668-2676.

[36] Q. Yue, Y. Wan, Z. Sun, X. Wu, Y. Yuan, P. Du, J. Mater. Chem. A, 2015, 3, 16941-16947.

[37] J. Chang, L. Feng, C. Liu, W. Xing, X. Hu, Angew. Chem. Int. Ed., 2014, $53,122-126$.

[38] D. P. Kumar, J. Choi, S. Hong, D. A. Reddy, S. Lee, T. K. Kim, ACS Sustainable Chem. Eng., 2016, 4, 7158-7166.

[39] L. Wang, Y. Wang, T. Xu, H. Liao, C. Yao, Y. Liu, Z. Li, Z. Chen, D. Pan, L. Sun, M. Wu, Nat. Commun., 2014, 5, 5357.

[40] W. Chen, L. Yan, Nanoscale, 2010, 2, 559-563.

[41] H. L. Guo, X. F. Wang, Q. Y. Qian, F. B. Wang, X. H. Xia, ACS Nano, 2009, 3, 2653-2659.

[42] Z. Fang, Y. Wang, J. Song, Y. Sun, J. Zhou, R. Xu, H. Duan, Nanoscale, 2013, 5, 9830-9838.

[43] Y. Si, E. T. Samulski, Nano Lett., 2008, 8, 1679-1682.

[44] S. Kim, S. W. Hwang, M. K. Kim, D. Y. Shin, D. H. Shin, C. O. Kim, S. B. Yang, J. H. Park, E. Hwang, S. H. Choi, G. Ko, S. Sim, C. Sone, H. J. Choi, S. Bae, B. H. Hong, ACS Nano, 2012, 6, 8203-8208.

[45] D. Pan, J. Jiao, Z. Li, Y. Guo, C. Feng, Y. Liu, L. Wang, M. Wu, ACS Sustainable Chem. Eng., 2015, 3, 2405-2413.

[46] S. J. Jeon, S. Y. Kwak, D. Yim, J. M. Ju, J. H. Kim, J. Am. Chem. Soc., 2014, 136, 10842-10845.

[47] G. Fomo, O. J. Achadu, T. Nyokong, J. Mater. Sci., 2018, 53, 538-548.

[48] F. Zhang, Q. Wen, M. Hong, Z. Zhuang, Y. Yu, Chem. Eng. J., 2017, 307, 593-603.

[49] J. Li, B. Shen, Z. Hong, B. Lin, B. Gao, Y. Chen, Chem. Commun., 2012, 48, 12017-12019.

[50] Q. Wang, J. He, Y. Shi, S. Zhang, T. Niu, H. She, Y. Bi, Z. Lei, Appl. Catal. B, 2017, 214, 158-167.

[51] Z. Qin, F. Xue, Y. Chen, S. Shen, L. Guo, Appl. Catal. B, 2017, 217, 551-559. 


\section{Graphical Abstract}

Chin. J. Catal., 2018, 39: 1753-1761 doi: 10.1016/S1872-2067(18)63135-3

Metal-free graphene quantum dots photosensitizer coupled with nickel phosphide cocatalyst for enhanced photocatalytic hydrogen production in water under visible light

Liang Zhu, Qiudi Yue, Daochuan Jiang, Huanlin Chen, Rana Muhammad Irfan, Pingwu Du* University of Science and Technology of China

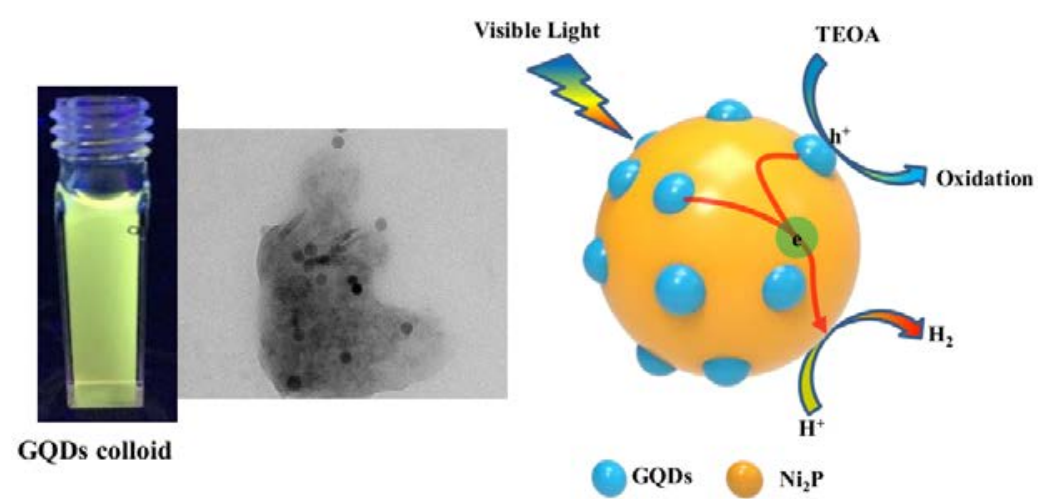

Metal-free $\mathrm{OH}$-functionalized graphene quantum dots ( $\mathrm{OH}-\mathrm{GQDs}$ ) were used as the photosensitizer coupled with $\mathrm{Ni}_{2} \mathrm{P}$ nanoparticles (NPs) for photocatalytic $\mathrm{H}_{2}$ production under visible light. The $\mathrm{H}_{2}$ production rate is $\sim 94$ times higher than that of bare $\mathrm{OH}-\mathrm{GQDs}$, which is even comparable to that of OH-GQDs with $1 \mathrm{wt} \%$ Pt cocatalyst. This enhancement is probably due to the semiconductor-cocatalyst interface interaction between $\mathrm{Ni}_{2} \mathrm{P}$ and $\mathrm{OH}-\mathrm{GQD}$ to facilitate efficient charge transfer process.

[52] M. Qian, S. Cui, D. Jiang, L. Zhang, P. Du, Adv. Mater., 2017, 29, 201704075.

[53] Z. Yan, Z. Sun, X. Liu, H. Jia, P. Du, Nanoscale, 2016, 8, 4748-4756.

[54] Z. Sun, H. Chen, L. Zhang, D. Lu, P. Du, J. Mater. Chem. A, 2016, 4, 13289-13295.

[55] D. Jiang, Z. Sun, H. Jia, D. Lu, P. Du, J. Mater. Chem. A, 2016, 4, 675-683.

[56] J. Zhou, S. Lin, Y. Chen, A. M. Gaskov, Appl. Surf. Sci., 2017, 403, 274-281.

[57] P. Ye, X. Liu, J. Iocozzia, Y. Yuan, L. Gu, G. Xu, Z. Lin, J. Mater. Chem. A, 2017, 5, 8493-8498.
[58] S. W. Cao, Y. P. Yuan, J. Fang, M. M. Shahjamali, F. Y. Boey, J. Barber, S. C. Joachim Loo, C. Xue, Int. J. Hydrogen Energy, 2013, 38, 1258-1266.

[59] L. Huang, X. Wang, J. Yang, G. Liu, J. Han, C. Li, J. Phys. Chem. C, 2013, 117, 11584-11591.

[60] S. Liu, Z. Chen, N. Zhang, Z. R. Tang, Y. J. Xu, J. Phys. Chem. C, 2013, $117,8251-8261$.

[61] H. Yu, Y. Zhao, C. Zhou, L. Shang, Y. Peng, Y. Cao, L. Z. Wu, C. H. Tung, T. Zhang, J. Mater. Chem. A, 2014, 2, 3344-3351.

[62] H. Zhao, S. Sun, P. Jiang, Z. J. Xu, Chem. Eng. J., 2017, 315, 296-303.

\section{非金属光敏剂石墨烯量子点与磷化镍耦合用于可见光光催化制氢}

祝 亮, 岳秋地, 江道传, 陈涣淋, Rana Muhammad Irfan, 杜平武 ${ }^{*}$ 中国科学技术大学, 材料科学与工程系, 中国科学院能量转换材料重点实验室, 能源材料化学协同创新中心, 合肥国家微尺度物理实验室, 安徽合肥230026

摘要: 利用光催化反应制取氢气是满足未来能源可持续利用的一个很有效的方法. 然而, 如何去开发和利用高效且稳定的 非金属光催化剂用于产氢反应是目前所面临的一个巨大的挑战. 最近, 非金属纳米碳基材料由于其诸多优点而吸引了人 们广泛的关注, 比如价格低廉、环境友好和良好的稳定性等. 另外, 石墨烯量子点由于具有很好的水溶性、低毒性, 良好的 生物兼容性和很好的光学稳定性等优点而被当作是一种能够替代传统量子点的很有前途的材料. 除此之外, 石墨烯量子 点的带隙还可以通过控制其颗粒大小和其表面所带的官能团来进行灵活调控. 另一方面, 金属磷化物(磷化镍、磷化钴等) 已经被证实了是很好的水分解制氢的非贵金属助催化剂, 它们可以加快光生电子和空穴的分离, 从而提高光催化活性.

本文利用非金属光敏剂石墨烯量子点与非贵金属助催化磷化镍进行耦合制备复合光催化剂, 实现了在可见光照射下 进行光催化制氢. 在最优条件下, 复合光催化剂的产氢速率为空白石墨烯量子点的 94 倍, 甚至与在空白量子点上负载1.0 wt \% Pt的产氢速率相当. 产氢速率的大幅度提升可能是由于在石墨烯的量子点和磷化镍之间形成了半导体-金属接触界 面, 从而更有效地促进了光生载流子的传输过程.

石墨烯量子点本身有着很好的水溶性, 从而利用机械摚拌的方法与磷化镍进行耦合, 并在可见光下进行产氢反应. 本 
文采用红外光谱(FTIR)、透射电镜(TEM)、紫外可见光谱(UV-Vis)和苂光光谱(PL)等表征手段研究了空白量子点表面所 带的官能团、尺寸大小和光学性能. 采用TEM和PL等表征手段来研究复合光催化剂的形貌和产氢性能提高的原因.

对于空白量子点, FTIR结果表明, 其表面带有-OH等官能团; TEM结果表明, 它的尺寸大小大概在 $3.6 \pm 0.5 \mathrm{~nm}$; UV-Vis 结果表明, 其在可见光区域有着很强的光吸收; PL结果表明, 其在波长约为 $540 \mathrm{~nm}$ 处有着很强的吸收峰, 所对应的带隙约为 $2.3 \mathrm{eV}$. 对于复合光催化剂, TEM测试结果表明石墨烯量子点在磷化镍上随机分布; 从PL结果可见, 复合光催化剂的荧光 强度明显降低, 说明了光生电子从量子点到磷化镍的有效转移, 这也是光催化活性提高的重要原因.

关键词: 非贵金属; 光催化; 产氢; 石墨烯量子点; 磷化镍

收稿日期: 2018-06-29. 接受日期: 2018-07-06. 出版日期: 2018-11-05.

*通讯联系人. 电话/传真: (0551)63606207; 电子信箱: dupingwu@ustc.edu.cn

基金来源：国家重点研发计划(2017YFA0402800); 国家自然科学基金(51772285,21473170); 中央高校基本科研业务费专项资金. 本文的电子版全文由Elsevier出版社在ScienceDirect上出版(http://www.sciencedirect.com/science/journal/18722067). 